\title{
Arsenic toxicity: an overview
}

\begin{abstract}
Heavy metals are member of ill-defined subset of elements, weathered from natural rock formations, widely distributed in the Earth's crust. Generally, heavy metals occurred in particulate or dissolved form in soils, rivers, lakes, and seawater and seafloor sediments. Most of the metals originate from rocks of igneous, sedimentary or transformed by intense heat and pressure processes. Heavy metals exhibit metallic properties that mainly include the transition metals, some metalloids, lanthanides and actinides. $^{1}$
\end{abstract}

Volume 3 Issue I - 2019

\section{Rekha bhadauria}

School of Studies in Botany, Jiwaji University, India

\author{
Correspondence: Rekha bhadauria, School of Studies in \\ Botany, Jiwaji University, Gwalior, India, \\ Email rekhabhadauria@yahoo.com
}

Received: December 08, 2017 | Published: January 03, 2019

\section{Introduction}

Arsenic (As) is a heavy metal with a name derived from the Greek word arsenikon, (meaning=potent). As (Arsenic) is a non-essential, nonmetallic carcinogenic element, occurs in many environments and highly toxic to all life forms including plants. ${ }^{2}$ The earth's crust is an abundant natural source of arsenic (As). It is present in more than 200 different minerals; the most common of which is called arsenopyrite. About one-third of the As in the Earth's atmosphere is of natural origin. The elements occur in environment in different oxidation states are: As (V), As (III), As (0) and As (-III). Some of the most commonly occurring forms of As in the environment include Arsenite (As(III)), arsenate $(\mathrm{As}(\mathrm{V}))$, monomethylarsenate, and dimethyl arsenate, ${ }^{3-6}$ out of these arsenate and arsenite are the main forms present in the soil. ${ }^{7}$ Inorganic arsenic compounds are formed in the environment, when arsenic combines with oxygen, chlorine and sulfur. In animals and plants arsenic combines with carbon and hydrogen to form organic arsenic compounds. Arsenic cannot be easily destroyed and can only be converted into different forms or transformed into insoluble compounds in combination with other elements, such as iron. ${ }^{8}$ Toxicity of widely distributed metalloid depends on the state of the arsenic, solubility, duration of exposure and the individual involved. Most of the anthropogenic activities and natural processes are mainly responsible for worldwide arsenic contamination. ${ }^{9}$ In the past decade, the global input of As to soil by human activities was estimated to be between 52,000 and 112,000 tons per year. ${ }^{10}$ Therefore, higher concentrations of heavy metals have been recorded because of agricultural and industrial activities. The genesis of heavy metals may be traced back to 1950 s.

One of the most famous cases of heavy metal pollution occurred in Minamata, Japan in the 1950s. The cause of this disaster has been traced to the dumping of about 27 tons mercury compounds by the Chisso Corporation into Minamata Bay during the 1950s and 1960s. The people of Minamata consumed fish and shellfish from the Bay in their diet and this lead to an accumulation of toxic methyl mercury in their bodies. Over 3000 victims have been recognized as having "Minamata Disease". The episodes of Minamata and Itai Itai diseases in Japan have brought to a sharp focus for the far reaching public health. ${ }^{11}$ Most of the essential heavy metals are important constituents of pigments and enzymes, especially $\mathrm{Cu}, \mathrm{Ni}, \mathrm{Zn}, \mathrm{Co}, \mathrm{Fe}$ and $\mathrm{Mo}$ for algae and plants; whilst some of the metals, especially cadmium (Cd), lead $(\mathrm{Pb})$, mercury $(\mathrm{Hg})$ and metalloids such as Arsenic (As), are toxic in higher concentrations because of disrupting enzyme functions context to many organic compounds, are not decomposed by the microbiological activity. ${ }^{12}$ Most of the heavy metals contaminate soil, water, vegetables and fruits. A number of commonly assessed heavy metals in vegetable and soil, are $\mathrm{As}, \mathrm{Pb}, \mathrm{Se}, \mathrm{Zn}, \mathrm{Cr}, \mathrm{Ni}, \mathrm{Mo}$, $\mathrm{Fe}, \mathrm{Co}, \mathrm{Mn}, \mathrm{Cu}$ and $\mathrm{Cd}$. Mainly As (V) and As (III) inorganic forms of arsenic occur and plant takes up Arsenic as As (V). In plants arsenic accumulates in the tissues of the different parts of the plants affecting adversely growth and productivity. Its effects are due to the suppression of the high-affinity phosphate/As uptake system ${ }^{13,14}$ stress, various physiological disorders in plants, inhibition in growth of the plant ${ }^{15,16}$ and finally death. As (III) reacts with sulfhydryl groups of enzymes and tissue proteins, inhibiting cellular function, causing death. ${ }^{17,14}$ As is accumulated mainly in the root system and it causes many physiological changes, ${ }^{18,19,14}$ interfere with metabolic processes, inhibits plant growth, and ultimately reduction of crop productivity. ${ }^{20,21}$ Arsenic concentration typically varies from below $10 \mathrm{mgkg}-1$ in noncontaminated soils ${ }^{22}$ to as high as $30,000 \mathrm{mg} \mathrm{kg}^{-1}$ in the contaminated soils. ${ }^{23}$ Permissible limit of arsenic in agricultural soils is $20 \mathrm{mg} / \mathrm{kg}$ soil, while 5-ppm arsenic in soil is found toxic to sensitive crops. Despite its low crustal abundance $(0.0001 \%)$, As is widely distributed in nature and is commonly associated with metal ores such as copper, lead, and gold. ${ }^{24,25}$ Different organic and inorganic As compounds have been identified in the soil-plant environment. ${ }^{26,14}$ In aerated soils used for crops such as wheat, maize and most vegetables, mainly As $(\mathrm{V})$ is present and, as such, is likely to be in the solid phase.

Therefore, in such soils, As in groundwater used for irrigation is quickly adsorbed by iron hydroxides and becomes largely unavailable to plants. In anaerobic soil conditions such as occur in flooded paddy fields, Arsenic is mainly present as As (III) and is dissolved in the soil-pore water (the soil solution).$^{27}$ It is thus more readily available to plant roots. The literature about the accumulation of heavy metals in food plants shows that both leafy and nonleafy vegetables are good accumulators of heavy metals. Reports shows that bioaccumulation pattern of heavy metals in nonleafy vegetables was leaf $>$ root $\approx$ stem $>$ tuber and these heavy metals may manipulate the nutritional values, thus heavy metals have strong influence on nutritional values. Therefore, plants grown on metal-contaminated soil are nutrient deficient and consumption of such vegetables may lead to nutritional deficiency in the population particularly living in developing countries which are already facing the malnutrition problems. ${ }^{28,43,44,45}$ Arsenic can find its way into the grains of plants, such as rice and wheat, and into vegetables and fruit plants ${ }^{29-32}$ through irrigation with As contaminated water. Rice is the major crop in areas where severe arsenic contamination occurs ${ }^{33}$ it has been reported to accumulate up to $2 \mathrm{mgkg}^{-1}$ Arsenic in grains ${ }^{34}$ and up to $92 \mathrm{mgkg}^{-1}$ in straw..$^{35}$ The diet of many rice consumers is, therefore, under threat from Arsenic contamination. ${ }^{29}$ Regarding the route of human exposure to arsenic, rice has been considered as a potentially important source/ route in populations with rice based diets. ${ }^{36}$ Incidences of arsenic 
contamination in rice grains has also been reported in different rice varieties tested in Bangladesh. Arsenic levels ranging between 0.04 and $0.92 \mathrm{mg} / \mathrm{kg}$ in rice samples obtained from 299 markets in 25 (of 64) districts across Bangladesh; the samples included several different rice varieties from irrigated and rainfed land and from areas with high and low-As tube well water. ${ }^{37}$

Most common symptoms in As-stressed plants are alteration of adenosine triphosphate (ATP), chlorophylls and photosynthesis system by arsenic (As) pollution, interveinal necrotic ${ }^{38,14}$ and whitish chlorotic symptoms. ${ }^{39}$ Arsenic damages the chloroplast membrane and disorganizes the functions of integral photosynthetic process. ${ }^{15} \mathrm{~A}$ significant decrease in pigment synthesis due to the lack of adaptive adjustments of pigment synthesis to high As levels and reduced rate of $\mathrm{CO} 2$ fixation and functional activity of photo system II (PSII) are observed in plants growing under As stress conditions. ${ }^{15}$ Heavy metals at toxic levels have the capability to interact with several vital cellular biomolecules such as nuclear proteins and DNA, leading to excessive augmentation of reactive oxygen species (ROS). This would inflict serious morphological, metabolic, and physiological anomalies in plants ranging from chlorosis of shoot to lipid peroxidation and protein degradation ${ }^{40}$ as well as physiological disorder of rice (Oryza sativa L.) characterized by sterility of the florets / spikelet's leading to reduced grain yield. ${ }^{41,14}$ Another one of the most widespread important problems is Arsenic contamination of ground water found in many countries throughout the world due to leaching of naturally occurring As into drinking water aquifers. The sources of As include both natural i.e. through dissolution of As compounds absorbed onto pyrite ores into the water by geochemical factors ${ }^{42-45}$ and anthropogenic (through use of insecticides, herbicides, and phosphate fertilizers and from the semiconductor industry) processes. Arsenic contaminated water contains arsenous acid and arsenic acid or their derivatives. These are merely the soluble forms of arsenic near neutral $\mathrm{pH}$ and are extracted from the underlying rocks that surround the aquifer. ${ }^{46}$ Arsenic (As) poisoning from drinking water has been called the worst natural disaster in the history of mankind. ${ }^{47}$ However, the worst As contamination conditions encountered in Bangladesh and West Bengal (India) have been created due to natural processes. ${ }^{48}$ A 2007 study found that over 137 million people in more than 70 countries are affected by arsenic poisoning of drinking water. ${ }^{49}$ The problem becomes serious health concern after mass poisoning of water in Bangladesh. The acceptable level as defined by WHO for maximum concentration of arsenic in safe drinking water is $0.01 \mathrm{mg} / \mathrm{L}$. WHO has defined the areas under threat are: seven of the twenty districts of West Bengal have been reported to have ground water arsenic concentration above $0.05 \mathrm{mh} / \mathrm{L} .{ }^{49}$

In Bihar ground water in 13 districts has been found to be contaminated with arsenic with quantities exceeding $0.05 \mathrm{mg} / \mathrm{L}$. All these districts are situated closet to large rivers Ganga and Gandak. ${ }^{50}$ Arsenic also finds its way into the food chain, e.g. into rice, through irrigation practices using contaminated ground water. ${ }^{28}$ An estimated 200 million people worldwide are exposed to arsenic concentrations in drinking water that exceed the recommended limit of $10 \mu \mathrm{g} / \mathrm{l}^{51}$ as set out in the guidelines of the World Health Organization (WHO).$^{52}$

\section{Conclusion}

A report of 2015 indicates arsenic as potent carcinogen and is known to cause cancer of the skin, lung, kidney, bladder, and liver. ${ }^{46}$ It has been reported that if exposure occurs over a brief period time symptoms may include vomiting, abdominal pain, encephalopathy and watery diarrhea that contains blood. Long term exposure can result in thickening of the skin, darker skin, abdominal pain, diarrhea, heart disease, numbness and cancer. ${ }^{53}$ The majority of this exposed population lives in southern Asian countries such as Bangladesh, Cambodia, India, Nepal and Viet Nam. ${ }^{54}$

\section{Acknowledgments}

None.

\section{Conflicts of interest}

The author declares there is no conflicts of interest.

\section{References}

1. Babula P, Adam V, Opatrilova R, et al. Uncommon heavy metals, metalloids and their plant toxicity. Environ. Chem. Lett. 2008;6(4):189213.

2. Zhao FJ, Ma JF, Meharg AA, et al. Arsenic uptake and metabolism in plants. New Phytol. 2009;181(4):777-794.

3. Wang S, Mulligan CN. Occurrence of arsenic contamination in Canada: sources, behavior and distribution. Sci Total Environ. 2006;366(23):701-721.

4. Afton SE, Carton B, Caruso JA. Elucidating the selenium and arsenic metabolic pathways following exposure to the non-hyper accumulating Chlorophytum comosum, spider plant. J Exp Bot. 2009;60(4):12891297.

5. Kim KW, Bang S, Zhu Y, et al. Arsenic geochemistry, transport mechanism in the soil-plant system, human and animal health issues. Environ Int. 2009;35(3):453-454.

6. Zhu YG, Rosen BP. Perspectives for genetic engineering for the phytoremediation of arsenic-contaminated environments: from imagination to reality. Curr Opin Biotechnol. 2009;20(2):220-224.

7. Harper M, Haswell SJ. A comparison of copper, lead and arsenic extraction from polluted and unpolluted soils. Environ Technol Lett. 1988;9(11):1271-1280.

8. Choong TSY, Chauah TG, Robiah Y, et al. Arsenic toxicity, health hazards and removal of techniques from water: an overview. Desalination. 2007;217(1-3):139-166.

9. Hettick BE, Canas Carrell JE, French AD, et al. Arsenic: a Review of the Element's Toxicity, Plant Interactions, and Potential Methods of Remediation. Journal of Agricultural and Food Chemistry. 2015;63(32):7097-7107.

10. Nriagu JO, Pacyna JM. Quantitative assessment of worldwide contamination of air, water and soils by trace metals. Nature. 1988;333(6169):134-139.

11. Agrahari KC. Heavy metals in aquatic ecosystem some environmental implications. Everyman's science. 2009;44(2):88-93.

12. Sharma P D. Ecology and environment (10 $\left.{ }^{\text {th }}\right)$ Rastogi publication. 2007.

13. Meharg AA, Macnair MR. Suppression of the high affinity phosphate uptake system: a mechanism of arsenate tolerance in Holcus lanatus L. J Exp Bot. 1992;43(4):519-524.

14. Smith SE, Christophersen HM, Pope S, et al. Arsenic uptake and toxicity in plants: integrating mycorrhizal influences. Plant Soil. 2010;327(1-2):1-21.

15. Stoeva N, Tz Bineva. Oxidative changes and photosynthesis in Oat plants grown in As-contaminated soil. Bulg J Plant Physiol. 2003;29 $(1-2): 87-95$. 
16. Stoeva N, Berova M, Vassilev A, et al. Efect of arsenic on some physiological parameters in bean plants. Biol Planta. 2005;49(2):293296 .

17. Ullrich Eberius C, Sanz A, Novacky A. Evaluation of arsenic and vanadate-associated changes of electrical membrane potential and phosphate transport in Lemna gibba GL. J Exp Bot. 1989;40(21):119128.

18. Marin AR, Masscheleyn PH, Patrik J. The influence of chemical form and concentration of arsenic on rice growth and tissue arsenic concentration. Plant Soil. 1992;139(2):175-183.

19. Wells BR, Gilmor J. Sterility in rice cultivars as influenced by MSMA rate and water management. Agron J. 1997;69(3):451-454.

20. Miteva E. Accumulation and effect of arsenic on tomatoes. Comm Soil Sci Plant Anal. 2002;33(11-12):1917-1926.

21. Stoeva N, Berova M, Zlatez Z. Physiological response of maize to arsenic contamination. Biol Planta. 2003;47(3):449-452.

22. Adriano DC. Trace elements in the terrestrial environment. 1986.

23. Vaughan GT. The environmental chemistry and fate of arsenical pesticides in cattle tick dip sites and banana land plantations. 1993.

24. Nriagu JO. Arsenic poisoning through the ages. In: Frankenberger WT, editors. Environmental chemistry of arsenic. 2002.

25. Srivastava M, Ma LQ, Singh N, et al. Antioxidant responses of hyper-accumulator and sensitive fern species to arsenic. J Exp Bot. 2005;56(415):1335-1342.

26. Quaghebeur M, Rengel Z. Arsenic speciation governs arsenic uptake and transport in terrestrial plants. Microchem Acta. 2005;151(34):141-152.

27. Xu XY, McGrath SP, Meharg AA, et al. Growing rice aerobically markedly decreases arsenic accumulation. Environ Sci Technol. 2008;42(15):5574-5579.

28. Khan A, Khan S, Khan MA, et al. The uptake and bioaccumulation of heavy metals by food plants, their effects on plants nutrients, and associated health risk: a review. Environ Sci Pollut Res Int. 2015;22(18):13772-13799.

29. Roychowdhury T, Uchino T, Tokunaga H, et al. Survey of arsenic in food composites from an arsenic affected area of west Bengal, India. Food Chem. Toxicol. 2002;40(11):1611-1621.

30. Meharg AA. Arsenic in rice-understanding a new disaster for SouthEast Asia. Trends Plant Sci. 2004;9(9):415-417.

31. Norra S. Impact of irrigation with As-rich groundwater on soil and crops: a geochemical case study in West Bengal delta plain, India. Appl Geochem. 2005;20(10):1890-1906

32. Zhao R. Arsenic speciation in moso bamboo shoot - a terrestrial plant that contains organ arsenic species. Sci Total Environ. 2006;371(13):293-303.

33. Williams $\mathrm{P}$ N. Variation in arsenic speciation and concentration in paddy rice related to dietary exposure. Environ Sci Technol. 2005;39(15):5531-5540.

34. Islam M R. Assessment of arsenic in the water-soil-plant systems in gangetic flood plains of Bangladesh. Asian J Plant Sci. 2004;3(4):489493.
35. Abedin MJ, Feldmann J, Meharg AA. Uptake kinetics of arsenic species in rice plants. Plant Physiol. 2002;128(3):1120-1128.

36. Sinha B, Bhattacharyya K. Arsenic toxicity in rice with special reference to speciation in Indian grain and its implication on human health. Science of Food and Agriculture. 2015;95(7):1435-1444.

37. Williams PN, Islam MR, Adomako EE, et al. Increase in rice grain arsenic for regions of Bangladesh irrigating paddies with elevated arsenic in ground waters. Environ Sci Technol. 2006;40(16):4903-4908.

38. Singh N, Ma LQ, Srivastava M, et al. Metabolic adaptations to arsenic induced oxidative stress in Pteris vittata L. and Pteris ensiformis L. Plant Sci. 2006;170(2):274-282.

39. Shaibur MR, Kitajima N, Sugewara R, et al. Hydroponic Sorghum. Water Air Soil Pollut. 2012;191:279-292.

40. Emamverdian A, Ding Y, Mokhberdoran, F, et al. Heavy metal stress and some mechanisms of plant defense response. The Scientific World Journal. 2015;18.

41. Rahman MA, Hasegawa H, Rahman MM, et al. Straighthead disease of rice (Oryza sativa L.) induced by arsenic toxicity. Environ Exper Bot. 2008;62(1):54-59.

42. Juhasz AL, Naidu R, Zhu YG, et al. Toxicity tissues associated with geogenic arsenic in the groundwater-soil-plant-human continuum. Bull Environ Contam Toxicol. 2003;71(6):1100-1107.

43. Cozzolino V, Pigna M, Di Meo V, et al. Effects of arbuscular mycorrhizal inoculation and phosphorus supply on the growth of Lactuca sativa L. and arsenic and phosphorus availability in an arsenic polluted soil under nonsterile conditions. Appl Soil Ecol. 2010;45(3):262-268.

44. Mondal P, Majumdar CB, Mohanty B. Laboratory based approaches for arsenic remediation from contaminated water; recent developments. $J$ Hazard Mater. 2006;137(1):464-479.

45. Verbruggen N, Hermans C, Schat H. Mechanisms to cope with arsenic or cadmium in plants. Curr Opin Plant Biol. 2009;12(3):364-372.

46. Kainth GS. Arsenic poisoning in drinking water: Huge Public-Health problem - OpED. Eurasia Review. 2015.

47. Tripathi RD, Srivastava S, Mishra S, et al. Arsenic hazards strategies for tolerance and remediation by plants. Trends Biotechnol. 2007;25(4):158-165

48. Arsenic in drinking water seen as threat. 2007.

49. Arsenic in drinking Water. 2011.

50. Groundwater in 13 Districts of Bihar contaminated with Arsenic. 2010.

51. Naujokas MF, Anderson B, Ahsan H, et al. The broad scope of health effects from chronic arsenic exposure: update on a worldwide public health problem. Environ Health Perspect. 2013;121(3):295-302.

52. http://www.who.int/mediacentre factsheets /fs372/en/

53. Ratnaike RN. Acute and chronic arsenic toxicity. Post grad Med J. 2003;79(933):391-396.

54. George CM, Sima L, Arias $\mathrm{MH}$, et al. Arsenic exposure in drinking water: an unrecognized health threat in Peru. Bull World Health Organ. 2014;92(8):565-572. 